\title{
Atmospheric tracers during the 2003-2004 stratospheric warming event and impact of ozone intrusions in the troposphere
}

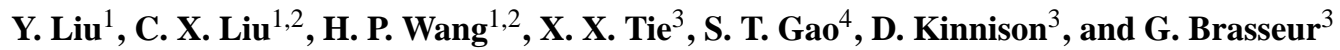 \\ ${ }^{1}$ Key Laboratory of middle Atmosphere and Global Environment Observation (LAGEO), Institute of Atmospheric Physics, \\ Chinese Academy of Sciences, Beijing, China \\ ${ }^{2}$ Graduate University of the Chinese Academy of Sciences, Beijing, China \\ ${ }^{3}$ National Center of Atmospheric Research, Boulder, Colorado, USA \\ ${ }^{4}$ Laboratory of Cloud-Precipitation Physics and Severe Storms (LACS), Institute of Atmospheric Physics, Chinese Academy \\ of Sciences, Beijing, China
}

Received: 15 April 2008 - Published in Atmos. Chem. Phys. Discuss.: 17 July 2008

Revised: 1 December 2008 - Accepted: 17 March 2009 - Published: 24 March 2009

\begin{abstract}
We use the stratospheric/tropospheric chemical transport model MOZART-3 to study the distribution and transport of stratospheric $\mathrm{O}_{3}$ during the remarkable stratospheric sudden warming event observed in January 2004 in the northern polar region. A comparison between observations by the MIPAS instrument on board the ENVISAT spacecraft and model simulations shows that the evolution of the polar vortex and of planetary waves during the warming event plays an important role in controlling the spatial distribution of stratospheric ozone and the downward ozone flux in the lower stratosphere and upper troposphere (UTLS) region. Compared to the situation during the winter of 20022003, lower ozone concentrations were transported from the polar region to mid-latitudes, leading to exceptional large areas of low ozone concentrations outside the polar vortex and "low-ozone pockets" in the middle stratosphere. The unusually long-lasting stratospheric westward winds (easterlies) during the 2003-2004 event greatly restricted the upward propagation of planetary waves, causing the weak transport of ozone-rich air originated from low latitudes to the middle polar stratosphere $(30 \mathrm{~km})$. The restricted wave activities led to a reduced extratropical downward ozone flux from the lower stratosphere to the lowermost stratosphere (or from the "overworld" into the "middleworld"), especially over East Asia. Consequently, during wintertime (15 December 15 February), the total downward ozone transport on $100 \mathrm{hPa}$ surface by the descending branches of Brewer-Dobson cir-
\end{abstract}

Correspondence to: $\mathrm{C} . \mathrm{X}$. Liu (lcx@mail.iap.ac.cn) culation over this region was about $10 \%$ lower during the 2003-2004 event. Meanwhile, the extratropical total crosstropopause ozone flux (CTOF) was also reduced by $\sim 25 \%$. Compared to the cold 1999-2000 winter, the vertical CTOF in high latitudes $\left(60^{\circ} \sim 90^{\circ} \mathrm{N}\right)$ increased more than 10 times during the two warming winters, while the vertical CTOF in mid-latitudes $\left(30^{\circ} \sim 60^{\circ} \mathrm{N}\right)$ decreased by $20 \sim 40 \%$. Moreover, during the two warming winters, the meridional CTOF caused by the isentropic transport associating with the enhanced wave activity also increased and played an important role in the total extratropical CTOF budget.

\section{Introduction}

One of the most prominent phenomena observed in the winter stratosphere is the development of stratospheric sudden warming (SSW) (Scherhag, 1952). These large disturbances are the consequence of the interactions between vertically propagating planetary waves and the zonal winds (Matsuno, 1971; Holton, 1976). Planetary wave activity is usually described through the Eliassen-Palm (EP) flux and its divergence (Edmon et al., 1980). The divergence of EP flux, which is related to the northward eddy flux of quasigeostropic potential vorticity, provides a measure of the momentum provided by the eddies to the mean flow as a result of planetary wave breaking. When the polar vortex is disturbed by the breaking of such waves (Baldwin and Holton, 1988), filaments of high potential vorticity air are stripped off the edge of the main vortex, and are gradually mixed with the surrounding low PV air (McIntyre and Palmer, 1983, 1984).

Published by Copernicus Publications on behalf of the European Geosciences Union. 
Disturbed polar vortex and major warming events are usually associated with the negative phase of the Arctic Oscillation (AO) (Thompson and Wallace, 1998), which provides a measure of the coupling between the stratosphere and the troposphere (Baldwin and Dunkerton, 1999). In summary, the stratosphere can be regarded as a recipient of energy and waves from the underlying troposphere, and as a modulator that organizes chaotic waves forcing from below and generates feedbacks by influencing the troposphere (Baldwin et al., 2003).

The interactions between the stratosphere and troposphere do not involve only dynamical processes, but also include radiative and chemical processes. Stratospheric ozone, although dynamically dominated in the lower stratosphere, strongly affects the coupled chemical, radiative, and dynamical interactions in the upper troposphere and lower stratosphere (UTLS) region. This coupling has a strong influence on temperature, circulation (Ramanathan, 1977), radiative transfer (Ramanathan et al., 1976; Ramanathan and Dickinson, 1979), and chemical concentrations (Tie and Brasseur, 1995). In addition, stratospheric ozone, which has been thought for a long time to be the major source of tropospheric ozone (Junge, 1962; Danielson, 1968), is now known to contribute globally to $20 \% \sim 50 \%$ of ozone below the tropopause (Follows and Austin, 1992; Roelofs and Lelieveld, 1997; Tie and Hess, 1997; Lelieveld and Dentener, 2000).

Large scale transport and cross-tropopause exchange of ozone is dominated by the Brewer-Dobson circulation (Brewer, 1949; Dobson, 1956), which comprises a two-cell structure in the lower stratosphere, with upwelling in the tropics and subsidence at middle and high latitudes, and a single mean meridional cell from the tropics into the winter hemisphere at higher altitudes (Plumb, 2002). According to the "downward control" principle (Haynes and McIntyre, 1987; Haynes et al., 1991), this poleward "extratropical pump" is driven by irreversible deposition of angular momentum caused by the breaking of upward propagating waves, together with some other eddy dissipation effects (Holton et al., 1995). However, according to Chen (1995), the vertical flux associated with this eddy-driven diabatic circulation should be regarded as the mass flux between the "overworld" and the "middleworld" (Hoskins, 1991), rather than that between the stratosphere and troposphere. Chen (1995) also suggests that the strong downward flux across the $100 \mathrm{hPa}$ level in the extratropical lower stratosphere of the northern winter (DJF) (Holton, 1990; Rosenlof and Holton, 1993) can be interpreted as the mass being transported downward from the "overworld" into the "middleworld". Analyses of the isentropic cross-tropopause ozone transport using SAGE II observations (Wang et al., 1998) suggests that the winter buildup of ozone-rich air in the extratropical "middleworld", between the isentropic surfaces of $330 \mathrm{~K}$ and $380 \mathrm{~K}$, should be attributed primarily to the wave-driven diabatic mass circulation during fall-winter-spring seasons, rather than to transport along isentropic surfaces. At least, there appears to be strong connections between the activity of upward planetary waves and the wintertime ozone distributions (Fusco and Salby, 1999; Salby and Callaghan, 2007).

The UTLS region, which is a transition zone between the convectively dominated troposphere and the stably stratified stratosphere, is an important passage for the upward propagation of tropospheric waves and the exchange of chemical tracers with distinct origins. The knowledge of wave process and mass flux in the UTLS region is critical to our understanding of the stratosphere-troposphere couplings, especially in winter. Stratospheric sudden warmings (SSW) are usually associated with significant changes in the general circulation in middle atmosphere, which induces a redistribution of the stratospheric air and trace gases (Manney et al., 1993, 1994). Moreover, the anomalous amplitude of upward wave activities associated with the SSW events may, to some extent, affect the vertical flux in the UTLS region.

After the unprecedented 2002 major stratospheric warming event that took place in Antarctica (Varotso 2002; Hoppel et al., 2003), the boreal winter witnessed another remarkable major stratospheric warming in January, 2004 (Manney et al., 2005). Moreover, this warming event was further complicated by the occurrence of an energetic particle precipitation (EPP) event (López-Puertas et al., 2005; Randall et al., 2005; Rohen et al., 2005). Recently, more studies had analyzed the vertical couplings between mesosphere and stratosphere( Pancheva et al., 2008) and the downward transport of nitrogen oxides (Clilverd et al., 2006; Seppälä et al., 2007; Funke et al., 2008) after this event. Vogel et al. (2008) numerically quantified the effects of the EPP event on the stratospheric ozone losses. In order to avoid the potential influence of this EPP event in our data analysis, only the ozone variations in the middle and lower stratosphere will be considered here. The downward ozone flux in the UTLS region will be derived from a simulation made with a detailed chemical transport model (CTM) driven by analyzed winds and temperature.

This paper is organized in the following way. Section 2 introduces the model used in the present study, and the satellite ozone data used in our analysis. A brief description of the basic characteristics of the 2003-2004 SSW event and of another SSW that occurred during 2002-2003 boreal winter are presented in Sect. 3. The impacts of the two SSW events on the distribution of stratospheric nitrous oxide $\left(\mathrm{N}_{2} \mathrm{O}\right)$ and ozone $\left(\mathrm{O}_{3}\right)$ are compared in Sect. 4. Section 5 analyzes the downward ozone flux across $100 \mathrm{hPa}$ surface and the crosstropopause ozone flux (CTOF) as derived for both warming and cold winters. In Sect. 6, a summary of the major findings is provided. 


\section{Model and data description}

\subsection{MOZART model}

In this study, we use the middle atmospheric version of the three-dimensional Model for Ozone And Related chemical Tracers, version 3 (MOZART-3), which is an extension to the middle atmosphere of its former tropospheric versions (Brasseur et al., 1998; Hauglustaine et al., 1998; Horowitz et al., 2003). This new version of MOZART (Kinnison et al., 2007) accounts for chemical processes from the Earth's surface to the lower thermosphere. This model includes not only a representation of advection, convective transport, boundary layer mixing, and dry/wet deposition, but also physical and chemical processes specific for the middle atmosphere, including vertical mixing associated with gravity wave breaking in the upper stratosphere and mesosphere, molecular diffusion of constituents above $80 \mathrm{~km}$, photochemical reactions associated with halogen compounds, stratospheric heterogeneous processes involving sulfate aerosols and polar stratospheric clouds, photolysis at short wavelengths $(>120 \mathrm{~nm})$ and auroral contribution to the chemical budget. This extended version of MOZART is more suitable for representing chemical/physical processes in stratosphere and for quantifying ozone fluxes from the stratosphere to the troposphere (Kinnison et al., 2007). The adopted boundary conditions, including the surface emissions, the $\mathrm{NO}_{\mathrm{x}}$ and $\mathrm{CO}$ emissions from aircraft and the $\mathrm{NO}_{\mathrm{x}}$ source associated with lightning are described in previous studies (Horowitz et al., 2003; Gettelman et al., 2004; Park et al., 2004).

In our study, the MOZART-3 model is applied to examine constituent STE (Stratosphere-Troposphere Exchange) processes, specifically ozone, in the UTLS region. This work builds on three previous studies that have evaluated the validity of STE processes in MOZART-3. The first is the evaluation of seasonal variations of several trace constituents near the tropopause (Park et al., 2004). This study examined methane, water vapor, and nitrogen oxides $\left(\mathrm{NO}_{\mathrm{x}}\right)$ derived from Halogen Occultation Experiment (HALOE) satellite observations. The model results showed good agreement for methane and water vapor, but underestimated the nitrogen oxide abundance. It was postulated that this model low $\mathrm{NO}_{\mathrm{x}}$ was related to the lightning and convective parameterization used in MOZART-3. This work highlighted the importance of the Northern Hemisphere (NH) monsoons as regions for transport of constituents into the lowermost stratosphere. This work was extended in Gettelman et al. (2004) where the impact of the NH summer monsoon circulations on STE was specifically examined. This study concluded that a simulation using observed winds (same ECMWF winds used in this study) was able to represent transport events from aircraft and that these events can explain the global correlations of ozone and water vapor around the tropopause. A third study, Pan et al. (2007) was recently completed using MOZART-3 driven with both ECMWF and climate model meteorological fields. Diagnostics were created to evaluate model performance in the extratropical UTLS region. Overall the model results showed qualitative agreement with the observation in the location of the chemical transition across the extratropical tropopause. These studies give confidence that the MOZART-3 model driven with ECMWF meteorological fields is appropriate for use in STE studies.

MOZART-3, like other off-line chemical-transport model, can be run at any reasonable time steps and spatial resolutions. In our study, the adopted model configuration includes 96 Gaussian grid cells in latitude and 192 equidistant in longitude, which represents a horizontal resolution of approximately 1.875 degree in both latitude and longitude. The model is driven with dynamical quantities taken from the ECMWF operational analysis performed every $6 \mathrm{~h}$. The simulation starts on 1 December 2003 and proceeds until 15 February 2004.

In order to highlight the specific impact of the 2003-2004 SSW event on the distribution of stratospheric ozone distribution, an experiment for another more "typical" warming event that took place in January, 2003 is also performed. In this case, the simulation extends from 1 December 2002 to 15 February 2003. Moreover, the simulation of the cold 19992000 winter (Manney and Sabutis, 2000) is also used to highlight the impacts of above two SSW events. In the 3 experiments, the same initial conditions are used for the distribution of chemical tracers.

\subsection{MIPAS observation}

MIPAS (Michelson Interferometer for Passive Atmospheric Sounding) is a limb-scanning Fourier infrared spectrometer on board the European Environmental Satellite (ENVISAT); more detailed characteristics regarding the measurements by this spaceborne instrument are given by Carli et al. (2004) and Raspollini et al. (2006). The sun-synchronous polar orbit provides a global coverage with nearly 14 orbits per day at a horizontal resolution of approximately $500 \mathrm{~km}$. More than 20 trace constituents are observed in the upper troposphere and in the stratosphere.

Currently, the MIPAS level-2 operational products are provided by the European Space Agency (ESA). These products include the temperature, and the concentrations of $\mathrm{H}_{2} \mathrm{O}$, $\mathrm{CH}_{4}, \mathrm{~N}_{2} \mathrm{O}, \mathrm{O}_{3}, \mathrm{HNO}_{3}$ and $\mathrm{NO}_{2}$. In its original nominal measurement mode, MIPAS scanned the Earth limb at 17 tangent altitudes of $6,9, \ldots, 39,42,47,52,60$, and $68 \mathrm{~km}$. The vertical resolution is $3 \mathrm{~km}$ for the 13 lowermost tangent altitudes and increases to $8 \mathrm{~km}$ at the upper end of the limb scan. The retrieved ozone profiles have been validated by Cortesi et al. (2007). The MIPAS $\mathrm{O}_{3}$ partial columns were compared with coincided measurements from ozone sondes and ground-based lidar and microwave radiometers, it shows MIPAS $\mathrm{O}_{3}$ vertical profiles had the mean relative difference of $\pm 10 \%$ with the individual correlative data sets in the stratosphere. The retrieved temperature profiles have 

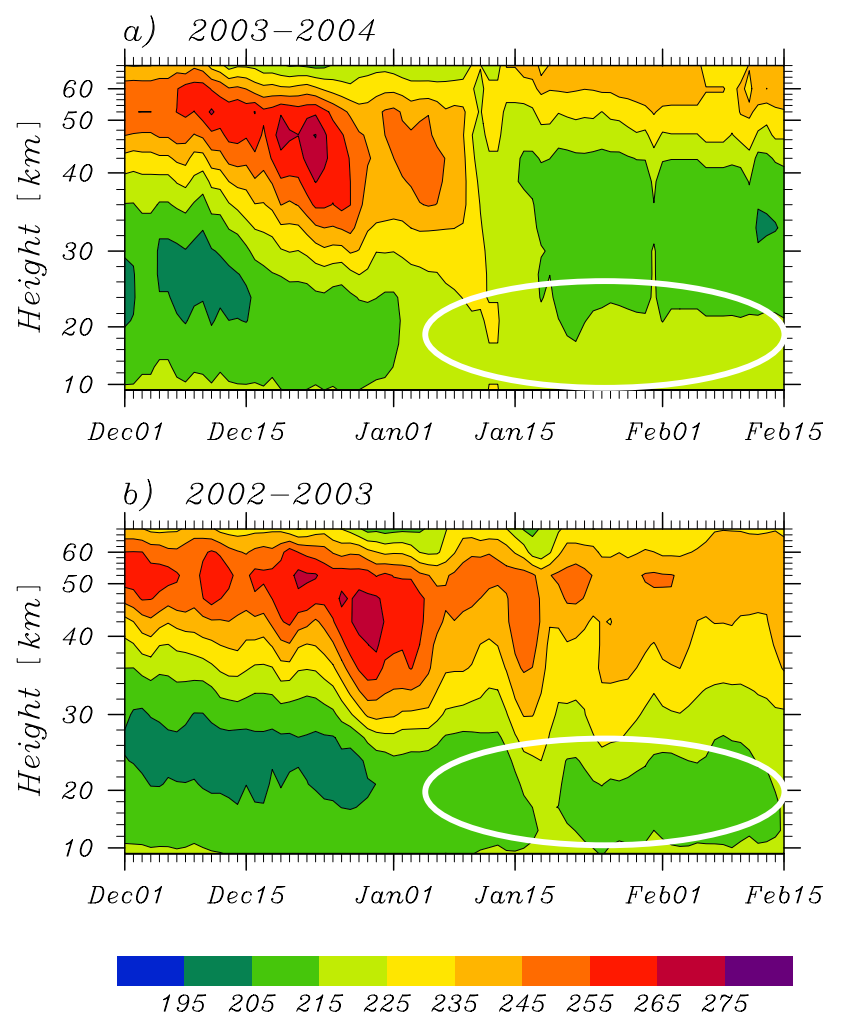

Fig. 1. Time evolution of MIPAS temperature (K) averaged from $60^{\circ} \mathrm{N}$ to the North Pole: (a) from 1 December 2003 to 15 February 2004; (b) from 1 December 2002 to 15 February 2003. The interval of the temperature contour lines is $4 \mathrm{~K}$.

been validated by Ridolfi et al. (2007), in which MIPAS temperature is compared with correlative measurements from radiosondes, lidars, in-situ and remote sensors operated either from the ground or stratospheric balloons. The results prove that the bias of the MIPAS profiles is generally smaller than 1 or $2 \mathrm{~K}$ within the stratosphere. Comparisons between ground-based FTIR and MIPAS $\mathrm{N}_{2} \mathrm{O}$ profiles at 5 NDACCsites distributed in both hemispheres show good agreement between MIPAS and FTIR $\mathrm{N}_{2} \mathrm{O}$ partial columns: the biases are below 5\% for all the stations and the standard deviations are below 7\% for the three mid-latitude stations, and below $10 \%$ for the high latitude ones (Vigouroux et al. 2007) .

In this study, the retrieved $\mathrm{O}_{3}, \mathrm{~N}_{2} \mathrm{O}$ and temperature profiles are used and re-gridded onto $73 \times 72$ (about $2.5 \times 5$ degree) horizontal grid meshes.

\section{The characteristics of the remarkable 2003-2004 SSW event}

Manney et al. (2005) have summarized the most prominent characteristics of the 2003-2004 SSW event during the boreal winter. Their analysis shows that this event was characterized by an extraordinarily long vortex disruption in the
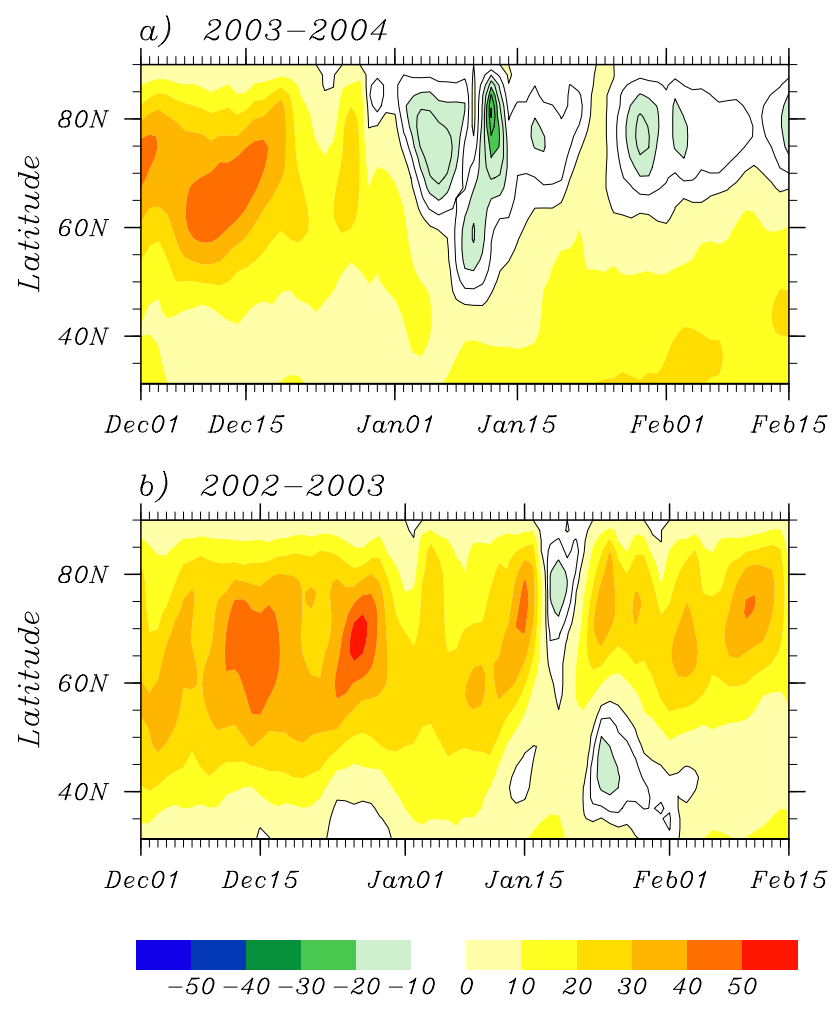

Fig. 2. Time evolution of the zonal-mean zonal wind (m/s) on $10 \mathrm{hPa}$ isobaric surface provided by ECMWF: (a) from 1 December 2003 to 15 February 2004; (b) from 1 December 2002 to 15 February 2003. Solid contour lines represent easterly winds. The interval of the wind contour lines is $10 \mathrm{~ms}^{-1}$.

lower and middle stratosphere, with a strong and rapid recovery of the vortex in the upper stratosphere. There is also indication that the progression of the warming from the upper to the lower stratosphere was slow.

An analysis of the MIPAS temperatures from $60^{\circ} \mathrm{N}$ to the North Pole shows that during the SSW event, a warming signal occurred as early as mid-December and propagated downward throughout the whole stratosphere with a rapid recovery in the upper stratosphere and an extraordinarily long persistent warming in the lower stratosphere (upper panel in Fig. 1). By contrast, the warming event observed in January 2003 was characterized by a similar winter warming near the stratopause but the warming signal remained in the upper and middle stratosphere during most of the winter. Several small and shallow downward intrusions, however, were observed after January 2003 (lower panel in Fig. 1). The major differences between the two events are highlighted by the white circles appearing in Fig. 1. During the 2003-2004 event, the zonal-mean zonal wind exhibited a prolonged reversal at high latitudes between 10 and $70 \mathrm{hPa}$ from January to midFebruary, as illustrated in Fig. 2 for the $30 \mathrm{~km}$ level. However, during the 2002-2003 event, the wind reversal occurred only during a few days in January 2003 (see Fig. 2). 


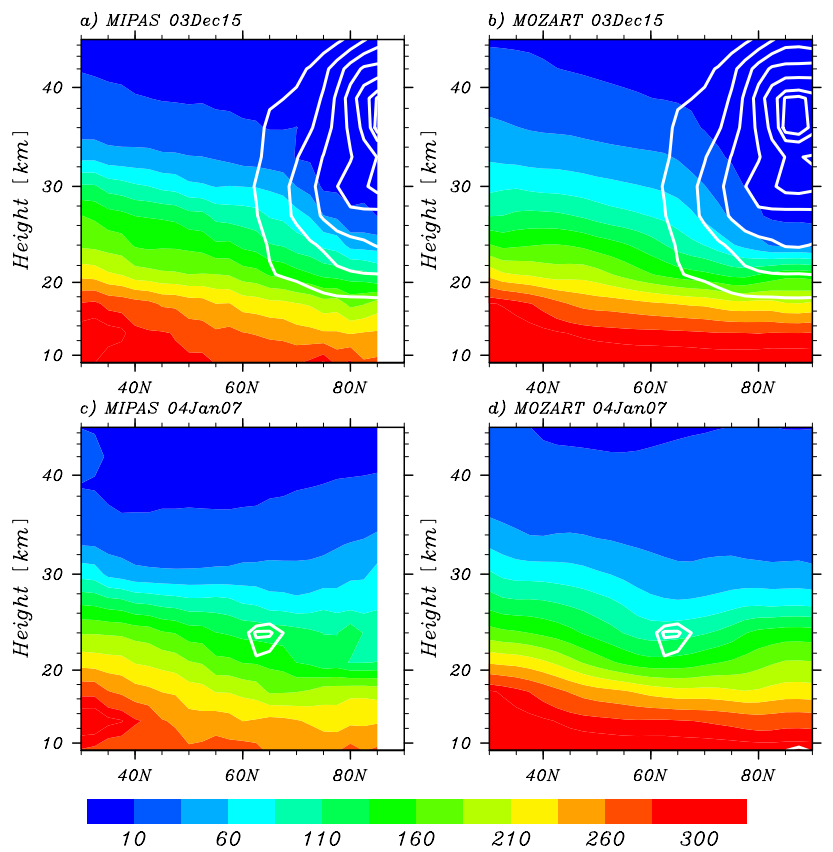

Fig. 3. Meridional cross-section of the zonal mean $\mathrm{N}_{2} \mathrm{O}$ mixing ratio (ppbv) poleward of $30^{\circ} \mathrm{N}$ before and during the 2003-2004 SSW: (a) MIPAS $\mathrm{N}_{2} \mathrm{O}$ on 15 December 2003; (b) MOZART $\mathrm{N}_{2} \mathrm{O}$ on 15 December 2003; (c) MIPAS $\mathrm{N}_{2} \mathrm{O}$ on 7 January 2004; (d) MOZART $\mathrm{N}_{2} \mathrm{O}$ on 7 January 2004. The MPV contours larger than 35 MPVU are shown by the solid lines with intervals of 10 MPVU (1 MPVU corresponds to $1 \times 10^{-6} \mathrm{~m}^{2} \mathrm{~s}^{-1} \mathrm{~K} \mathrm{~kg}^{-1}$ ).

The main differences between the two warming events can be summarized as follows: (1) The warming during the 2003-2004 winter was more pronounced in the lower stratosphere. (2) The easterly winds lasted to a considerably longer time period in the case of the 2003-2004 SSW.

\section{Impacts of SSW events on stratospheric $\mathrm{N}_{2} \mathrm{O}$ and $\mathrm{O}_{3}$ distributions}

Stratospheric warming events affect considerably the stratospheric circulation pattern as well as the mean meridional transport of chemical tracers. In order to exclusively consider the dynamical effect of the 2003-2004 SSW on the distribution of atmospheric constituents, the vertical and horizontal distributions of relatively inert nitrous oxide $\left(\mathrm{N}_{2} \mathrm{O}\right)$ are compared with the distributions of ozone $\left(\mathrm{O}_{3}\right)$. Meanwhile, the same method is applied to the more "typical" 2002-2003 SSW event, so that the impacts of the two warming events on stratospheric chemistry can be differentiated.

The EPP event from late October and early November 2003 had important effects on upper stratospheric ozone (Randall et al., 2005; Vogel et al., 2008). To focus our study on the SSW events, we analyze the relative change of ozone distribution at $30 \mathrm{~km}$. The MOZART simulation, which does

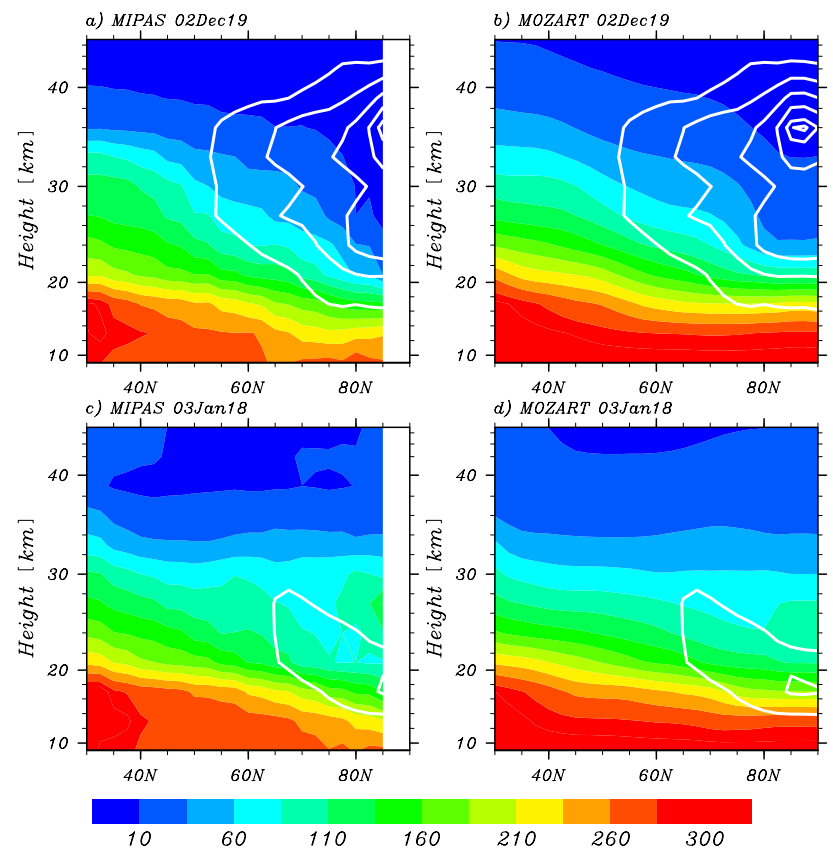

Fig. 4. Meridional cross-section of the zonal mean $\mathrm{N}_{2} \mathrm{O}$ mixing ratio (ppbv) poleward of $30^{\circ} \mathrm{N}$ before and during the 2002-2003 SSW: (a) MIPAS $\mathrm{N}_{2} \mathrm{O}$ on 19 December 2002; (b) MOZART $\mathrm{N}_{2} \mathrm{O}$ on 19 December 2002; (c) MIPAS $\mathrm{N}_{2} \mathrm{O}$ on 18 January 2003; (d) MOZART $\mathrm{N}_{2} \mathrm{O}$ on 18 January 2003. The MPV contours larger than 35 MPVU are shown by the solid lines with intervals of 10 MPVU.

not consider any EPP mechanism, is compared with the MIPAS observation.

Figures 3 to 6 compare the observed and calculated meridional cross-sections of the zonal mean $\mathrm{N}_{2} \mathrm{O}$ and $\mathrm{O}_{3}$ concentrations for the 2002-2003 and 2003-2004 warming winters under consideration. The distributions of $\mathrm{N}_{2} \mathrm{O}$ and $\mathrm{O}_{3}$ derived from MIPAS retrievals and calculated by MOZART-3 at $30 \mathrm{~km}$ for the two successive winters are also shown in Figs. 7 to 10 . In these figures, the polar vortex is represented by the modified PV contours (solid lines). The definition of the modified PV (referenced to the $475-\mathrm{K}$ potential temperature level) is provided by Lait (1994).

In Figs. 3 and 4, the observed vertical decrease in the distribution of stratospheric $\mathrm{N}_{2} \mathrm{O}$ is represented realistically by the model results. Before the occurrence of the SSW event, the vortices are stable throughout the middle stratosphere and there is a high correlation between the $\mathrm{N}_{2} \mathrm{O}$ concentrations and the position of the polar vortex in the middle stratosphere. For example, on 15 December 2003 (see Fig. 3a, b) and on 19 December 2002 (see Fig. 4a, b), the $\mathrm{N}_{2} \mathrm{O}$ concentrations are lower inside the stable vortex. A sharp horizontal gradient is observed near the edge of the vortex in both the MIPAS observations and the MOZART-3 simulation. Horizontal distributions at $30 \mathrm{~km}$ also show that, in 2003-2004 early winter, the polar vortex and the corresponding low $\mathrm{N}_{2} \mathrm{O}$ concentrations are located in the Arctic region with a small 

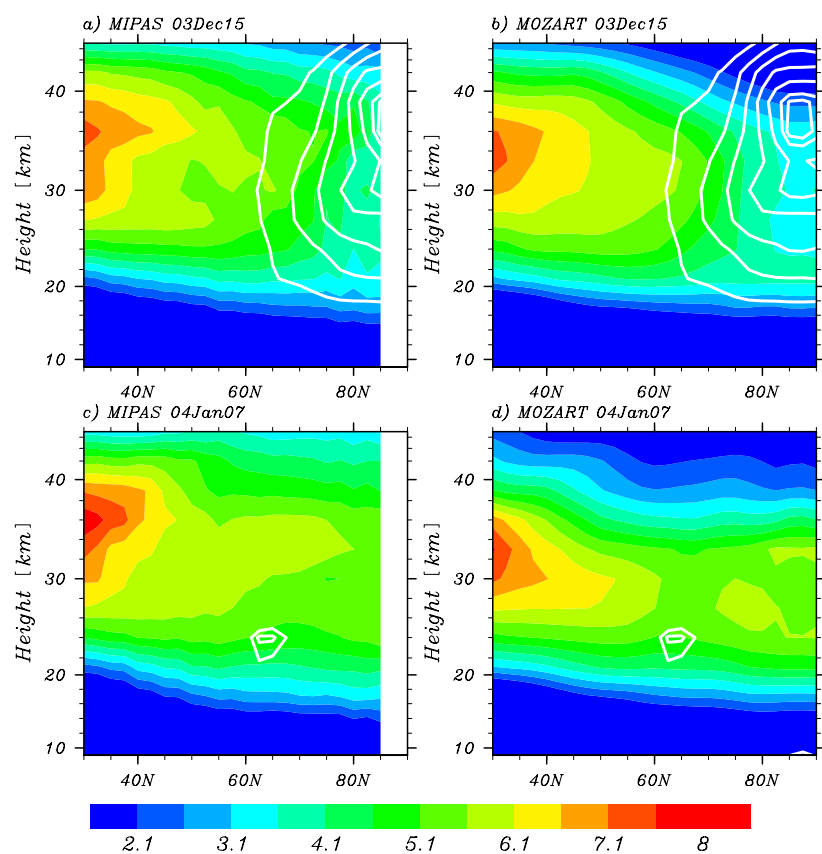

Fig. 5. Same as Fig. 3, but for the ozone mixing ratio (ppbv).

shift towards the North Atlantic and Northern Europe (see Fig. 7a, b). Starting in January, the SSW events have strong impacts on the distribution of stratospheric tracers. However, the effects on the stratospheric constituents are very different in both cases. On 18 January 2003, even though the middle stratosphere vortex is disturbed and moves away from the pole and the polar vortex with low $\mathrm{N}_{2} \mathrm{O}$ concentrations at $30 \mathrm{~km}$ elongate after mid-January (see Fig. 8c, d). But, the vortex in the lower stratosphere remains stable and is still located at the pole. As a result, the $\mathrm{N}_{2} \mathrm{O}$ concentrations are low in the Arctic region of the lower stratosphere (see Fig. 4c, d). By contrast, on 7 January 2004, the vortex becomes unstable and is displaced away from the pole, reaching the latitude of $60^{\circ} \mathrm{N}$. As a result, only a shallow trough remains in the zonal mean $\mathrm{N}_{2} \mathrm{O}$ concentrations (see Fig. 3c, d). Moreover, the dynamical disturbance has significant impacts on the $\mathrm{N}_{2} \mathrm{O}$ distribution after the vortex breakdown. For example, on 10 January 2004, two remnants of the diluted vortex can be seen at $30 \mathrm{~km}$ and air masses with high $\mathrm{N}_{2} \mathrm{O}$ concentrations originating from mid-latitudes reach the polar region (see Fig. 7c, d). The dramatic increase of mid-stratospheric $\mathrm{N}_{2} \mathrm{O}$ concentration in the polar region can generally be attributed to the enhanced poleward transport of $\mathrm{N}_{2} \mathrm{O}$-rich air with mid-latitude origin. However, there are differences between area of low $\mathrm{N}_{2} \mathrm{O}$ concentrations and the location of polar vortex. The main vortex with low $\mathrm{N}_{2} \mathrm{O}$ concentrations breaks into several small low concentration centers inside the remanent polar vortex. In addition, large areas of low $\mathrm{N}_{2} \mathrm{O}$ concentrations are found outside the polar vortex. As a result, $\mathrm{N}_{2} \mathrm{O}$ is further diluted as the warming event progresses.

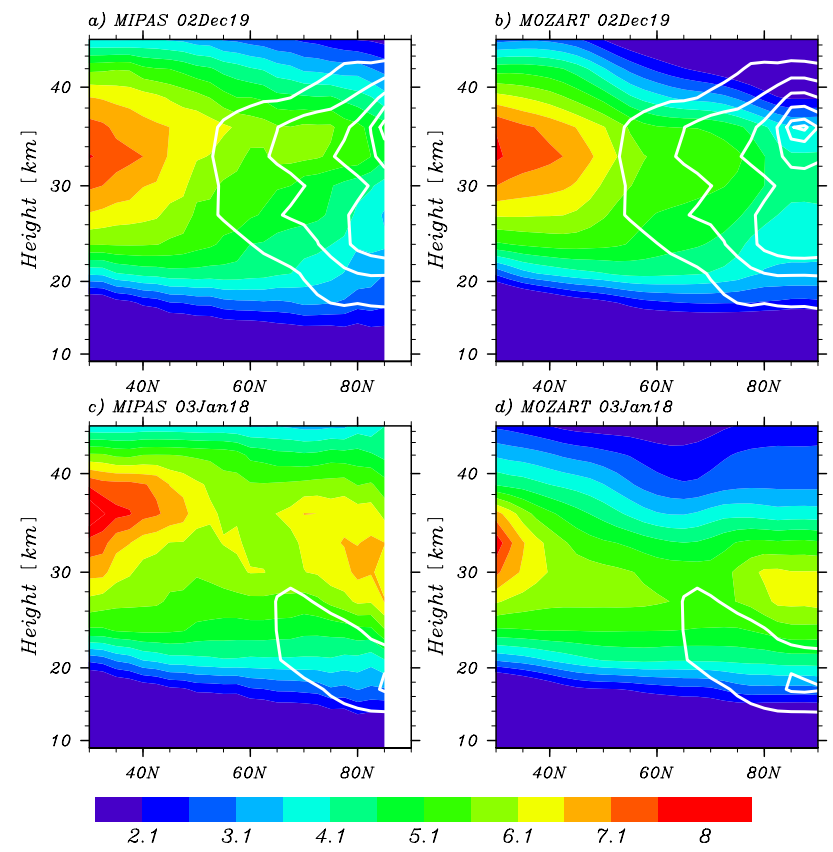

Fig. 6. Same as Fig. 4, but for the ozone mixing ratio (ppbv).
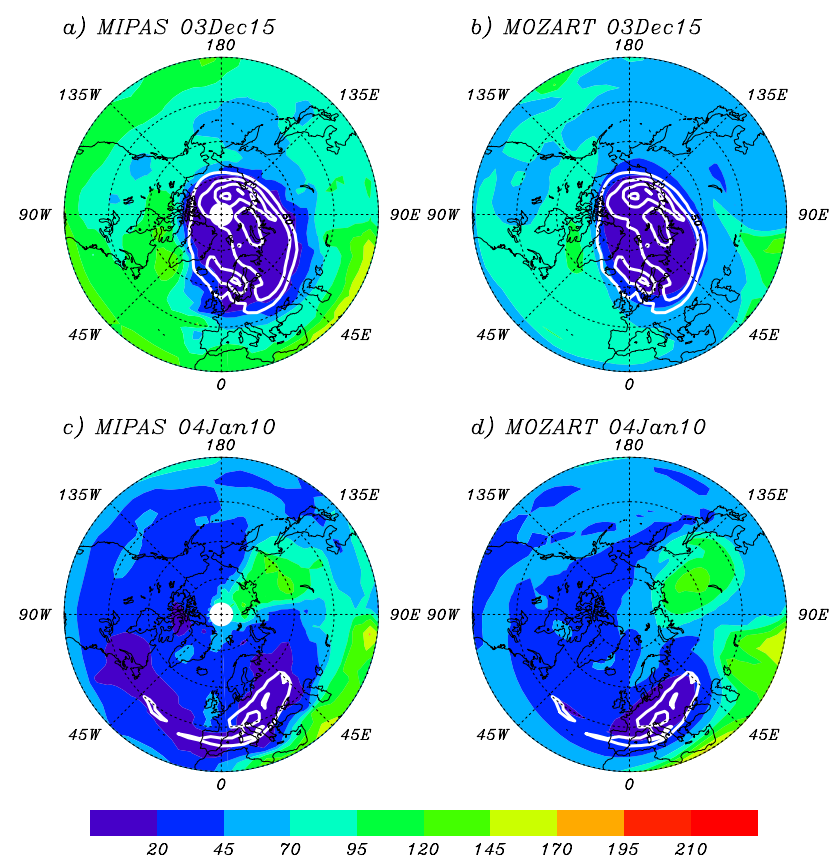

Fig. 7. Distributions of the $\mathrm{N}_{2} \mathrm{O}$ mixing ratio (ppbv) at $30 \mathrm{~km}$ poleward of $30^{\circ} \mathrm{N}$ before and during the 2003-2004 SSW: (a) MIPAS $\mathrm{N}_{2} \mathrm{O}$ on 15 Dec 2003; (b) MOZART $\mathrm{N}_{2} \mathrm{O}$ on 15 December 2003; (c) MIPAS $\mathrm{N}_{2} \mathrm{O}$ on 10 January 2004; (d) MOZART $\mathrm{N}_{2} \mathrm{O}$ on 10 January 2004. The MPV contours larger than 50 MPVU are also shown as the solid lines with the interval of 10 MPVU. 

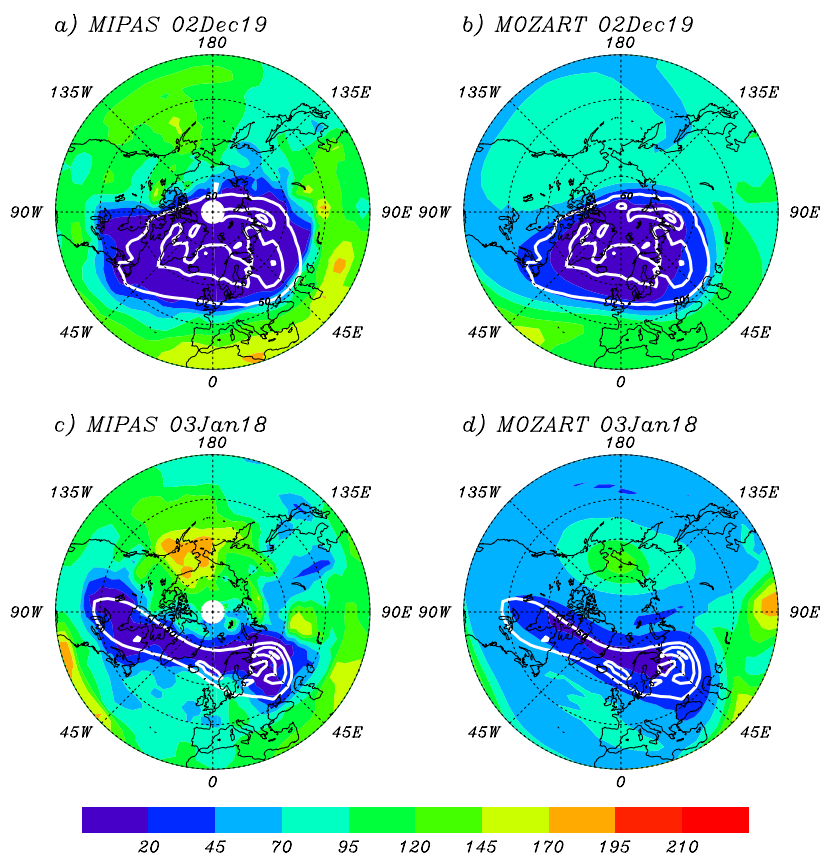

Fig. 8. Distributions of the $\mathrm{N}_{2} \mathrm{O}$ mixing ratio (ppbv) at $30 \mathrm{~km}$ poleward of $30^{\circ} \mathrm{N}$ before and during the 2002-2003 SSW (unit: ppbv): (a) MIPAS $\mathrm{N}_{2} \mathrm{O}$ on 19 December 2002; (b) MOZART $\mathrm{N}_{2} \mathrm{O}$ on 19 December 2002; (c) MIPAS $\mathrm{N}_{2} \mathrm{O}$ on 18 January 2003; (d) MOZART $\mathrm{N}_{2} \mathrm{O}$ on 18 January 2003. The MPV contours larger than 50 MPVU are also shown as the solid lines with the interval of 10 MPVU.

The simulated distributions of the zonal mean and horizontal $\mathrm{O}_{3}$ concentration are also generally consistent with the MIPAS observations (see Figs. 5, 6, 9 and 10). When the vortex is stable, the high ozone concentrations that stretch from low latitudes to higher latitudes in the middle stratosphere (from about $24 \mathrm{~km}$ to $40 \mathrm{~km}$ ), remains confined outside the polar vortex (as denoted by the modified PV contours). This is the case before the SSW events on 15 December 2003 (see Fig. 5a, b) and on 19 December 2002 (see Fig. 6a, b). This feature can also be figured out from the horizontal distribution at $30 \mathrm{~km}$ (see Figs. 9a, b and 10a, b). During the 20032004 SSW (e.g., on 7 and 10 January 2004) high ozone concentrations have been transported into the polar region as a result of the strong planetary wave disturbance. As highlighted above, in the middle of January, the split vortex shifts away from the polar region, causing a relatively low $\mathrm{O}_{3}$ concentration just at the location of the remaining vortex (see Figs. 5c, d and 9c, d). During the 2002-2003 SSW event (e.g., on 18 January 2003) the poleward transport of ozonerich air is also prohibited by the remnant vortex (see Fig. 6c, d). However, when compared with the 2003-2004 warming, the observed polar ozone concentrations in the middle stratosphere are obviously higher during the 2002-2003 winter (see Figs. 5c and 6c). This can be easily attributed to
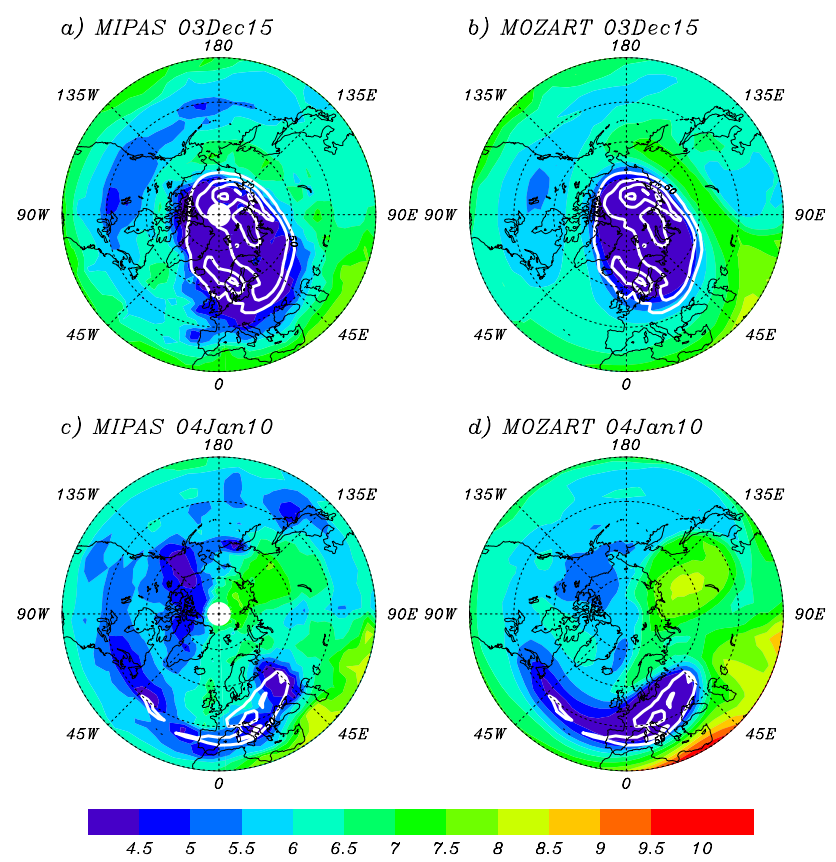

Fig. 9. Same as Fig. 7, but for the ozone mixing ratio (ppmv).
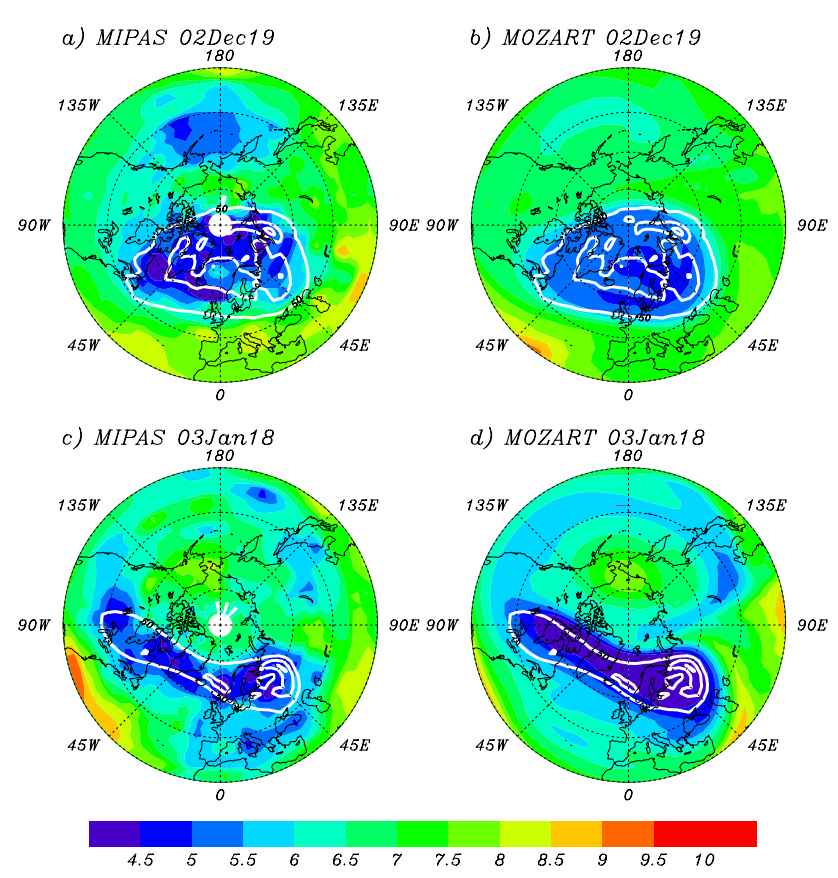

Fig. 10. Same as Fig. 8, but for the ozone mixing ratio (ppmv).

the effects of the EPP event (Randall et al., 2005; Vogel et al., 2008). However, the concentration inside the poleward transport of ozone-rich air is higher in 2002-2003 than in 2003-2004 (see Figs. 5d and 6d). This is consistent with the MOZART-3 calculation, which, however, does not account 
for any EPP mechanism. Thus, to some extent, these differences in ozone distributions should also result from the differences in the stratospheric dynamics between the two events. More details are provided in Sect. 5.

In addition, there are, however, differences in the behavior of the $\mathrm{O}_{3}$ and $\mathrm{N}_{2} \mathrm{O}$ : there is, for example, a low ozone center located over the North Pacific and/or North America, referred to as "low-ozone pockets" by Manney et al. (1995). This feature is observed in the middle stratospheric anticyclone during both SSW events, and is explained by the dynamical isolation of air masses at high latitudes over time periods that are long enough for local photochemical equilibrium to be approached (Morris et al., 1998). These "low-ozone pockets" are more prominent during the 2003-2004 event (see Figs. 9a, b and 10a, b), which suggests that the stratospheric anticyclone was larger during the 2003-2004 winter. After the dissipation of the SSW disturbance, the "low-ozone pockets" are further enhanced by the low $\mathrm{O}_{3}$ concentrations drawn off the polar vortex and are distorted by the intrusion of low-latitude air (see Figs. 9c, d and 10c, d).

As shown by the different figures, there is general consistency between the observed and simulated distributions of $\mathrm{N}_{2} \mathrm{O}$ and $\mathrm{O}_{3}$ concentrations. However, there are also differences in the magnitude of the concentrations of both compounds: some observed features are not reproduced, such as the overestimation/uderestimation of upper stratospheric $\mathrm{N}_{2} \mathrm{O} / \mathrm{O}_{3}$ concentrations and the positive $\mathrm{N}_{2} \mathrm{O}$ meridional gradient above $30 \mathrm{~km}$. Most of these discrepancies between MOZART and satellite observations can be attributed primarily to the fact that the initial conditions used in the MOZART model simulations did not result from an assimilation of satellite data. In addition, part of the difference in the strength of the structures in $\mathrm{O}_{3}$ and $\mathrm{N}_{2} \mathrm{O}$ may also be attributed to the MOZART- 3 transport scheme and the resolution of dynamics.

\section{Impacts of SSW on the extratropical UTLS ozone}

As indicated above, SSW events have important impacts on ozone concentrations in the lower stratosphere. As a result, the mass exchange between the upper troposphere and the lower stratosphere could also be affected by the intensity of the SSW with consequences for upper tropospheric ozone. In the following section, we analyze the variation of ozone in the extratropical UTLS region, with emphasis on the intrusion of stratospheric ozone-rich air into the lowermost stratosphere over East Asia and the cross-tropopause ozone flux (CTOF) in the northern extratropics. In MOZART-3 simulation, the 3 dimensional ozone fluxes (in $\mathrm{kg} / \mathrm{day}$ ) at each model grid were totaled daily.
Table 1. Zonal mean eddy heat flux $\left(\mathrm{v}^{\prime} \mathrm{T}^{\prime}\right)$ between $45^{\circ} \sim 75^{\circ} \mathrm{N}$ on the $100 \mathrm{hPa}$ isobaric surface (unit: $\mathrm{K}^{*} \mathrm{~m} / \mathrm{s}$ ): the two columns represent the averages for period-1 (15 December 15 January), and period 2 (15 January $\sim 15$ February) respectively.

\begin{tabular}{ccc}
\hline & 15 Dec-15 Jan & 15 Jan-15 Feb \\
\hline $2002-2003$ & 21 & 19 \\
$2003-2004$ & 24 & 16 \\
$1999-2000$ & 10 & 17 \\
\hline
\end{tabular}

\subsection{Variations of ozone in extratropical lower stratosphere}

Given the fidelity of the MOZART simulation to MIPAS observations illustrated in the previous section, there is some confidence in examining the ozone abundance where qualified observations are not available. Thus, in order to compare the impact of the two SSW events on the "middleworld" ozone abundance (Chen, 1995), we use the daily totaled vertical ozone flux on $100 \mathrm{hPa}$ from the simulation. The resulting vertical ozone fluxes on $100 \mathrm{hPa}$ level averaged for two periods (period-1: 15 December to 15 January; period-2: 15 January to 15 February) are considered for this comparison. In general, these two time periods can represent the situations during and after the both warming events respectively. Moreover, in order to provide a general picture about the inter-annual effects of the atmospheric waves to the extratropical UTLS ozone, we also use the simulation in the cold Arctic 1999-2000 winter (Manney and Sabutis, 2000) for a more convincing comparison.

The distributions of vertical ozone flux show similarities among the three cases. For example, the patterns of the downward ozone fluxes at $100 \mathrm{hPa}$ (see Fig. 11) are generally the same: the maximum centers of the downward ozone flux in the Northern Hemisphere are located in the Baikal area (East Asia) throughout the boreal winter for all three cases. This suggests that the intrusion of high ozone concentration into the lowermost stratosphere region over East Asia contributed substantially to the extratropical lowermost stratosphere ozone budget during the both warming winters and the cold winter. Obviously, during period-1 the downward ozone fluxes across $100 \mathrm{hPa}$ surface in two SSW cases are stronger than that in 1999-2000 winter. Moreover, during period-2, there is a clear enhancement in downward ozone flux for 1999-2000 case, while there exist a slight decrease in downward ozone fluxes for warming winters. However, there are still marked differences between the two SSW events. During the 2003-2004 winter, the downward ozone flux over East Asia was weaker and shifted slightly to the south compared to the situation in 2002-2003. The southward shift might be associated with a more pronounced southward extension of the East Asia trough during the 2003-2004 winter. 
Table 2. Total downward ozone flux (in Tg) over East Asia $\left(40^{\circ} \sim 65^{\circ} \mathrm{N}, 80^{\circ} \sim 150^{\circ} \mathrm{E}\right.$ ) across $100 \mathrm{hPa}$ isobaric surface: the first two columns correspond to period-1 (15 December 15 January) and period-2 (15 January 15 February) respectively and the last column is the sum of the first two column.

\begin{tabular}{cccc}
\hline & 15 Dec-15 Jan & 15 Jan-15 Feb & 15 Dec-15 Feb \\
\hline $2002-2003$ & 103 & 83 & 186 \\
$2003-2004$ & 100 & 71 & 171 \\
$1999-2000$ & 67 & 106 & 173 \\
\hline
\end{tabular}
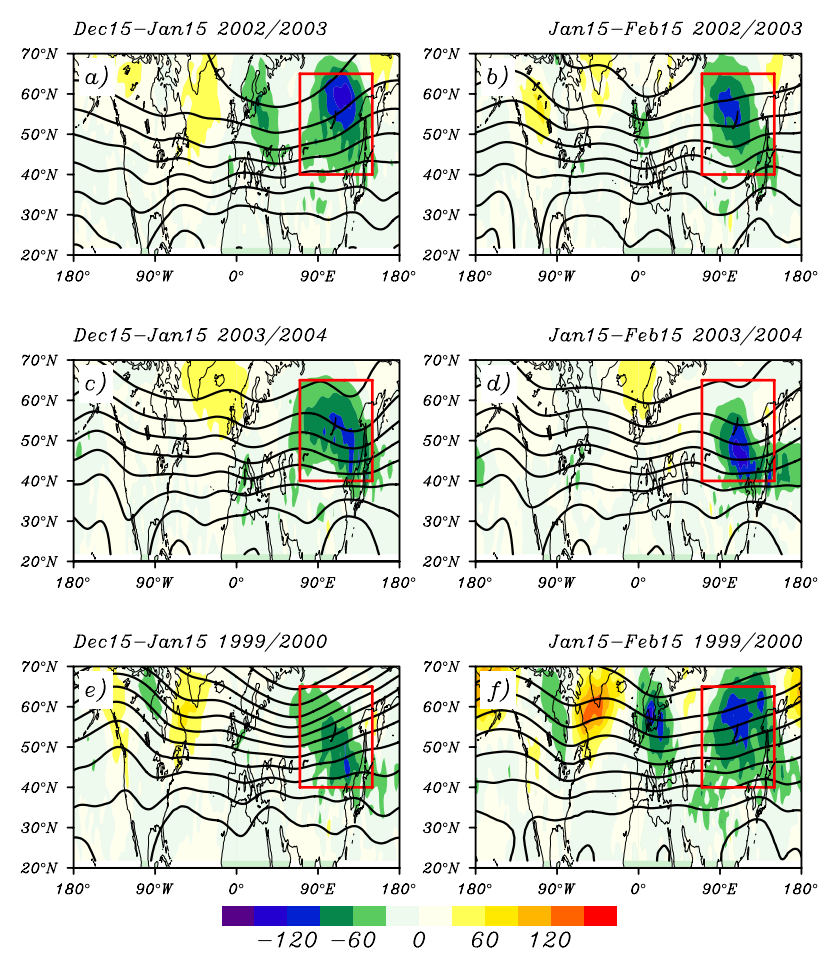

Fig. 11. Averaged vertical ozone flux $\left(10^{5} \mathrm{~kg} /\right.$ day $)$ provided by MOZART across the $100 \mathrm{hPa}$ isobaric surface before and after the SSW events. Panels (a), (b) represent the averaged fluxes for period-1, period-2 of the 2002-2003 winter respectively; panels (c), (d) correspond to the averaged fluxes for period-1, period-2 of the 2003-2004 winter respectively; panels (e), (f) correspond to the averaged fluxes for period-1, period-2 of the 2003-2004 winter respectively. The negative values represent the downward ozone flux. The contours of the geo-potential height are also shown by the solid lines with intervals of $100 \mathrm{~m}$. The area corresponding to East Asia $\left(40^{\circ} \sim 65^{\circ} \mathrm{N}, 70^{\circ} \sim 150^{\circ} \mathrm{E}\right)$ is highlighted by the red box.

Previous studies (e.g., Fusco and Salby, 1999; Newman and Nash, 2000) show that the zonal mean eddy heat flux $\left(\mathrm{v}^{\prime} \mathrm{T}^{\prime}\right)$, which is directly proportional to vertical component of the EP flux, can be used to quantitatively represent the wave activity that propagates from the troposphere into the stratosphere, and can be a proxy to represent the intensity of the Brewer-Dobson circulation. The 1-month averaged
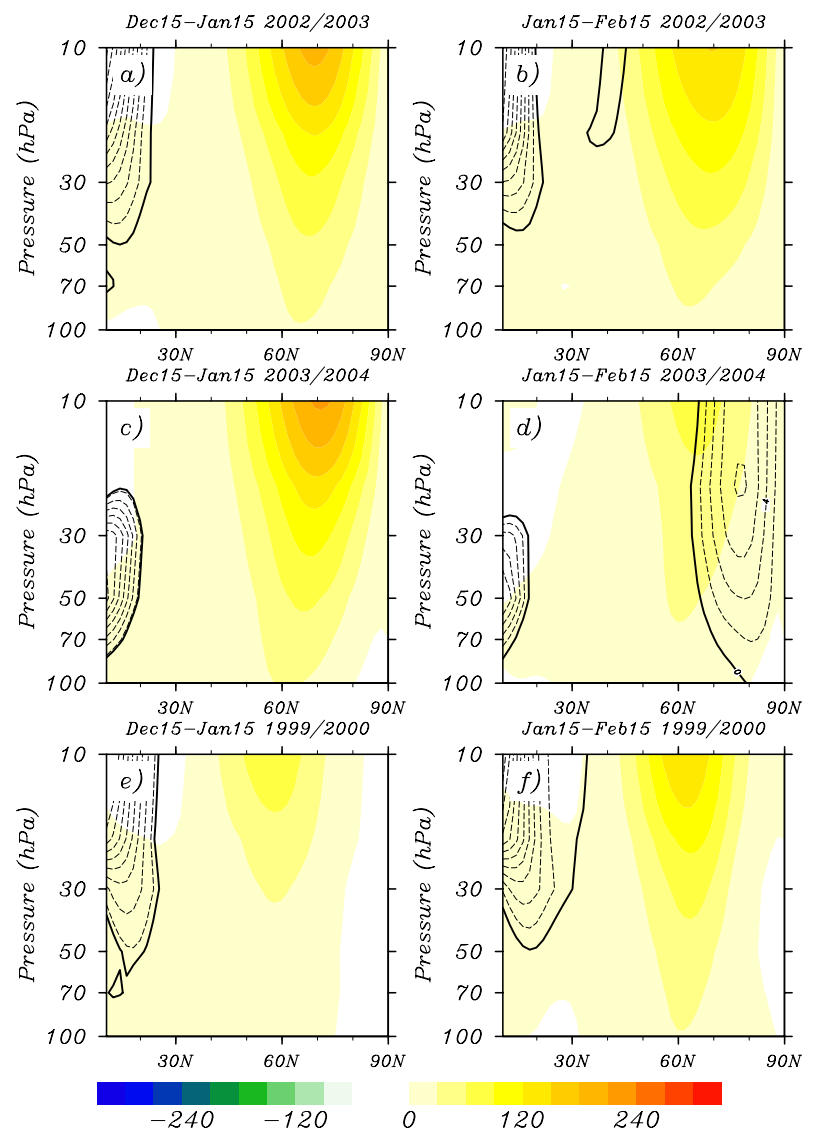

Fig. 12. Zonal-mean eddy heat flux $\left(\mathrm{K}^{*} \mathrm{~m} / \mathrm{s}\right)$ cross-section between 10 and $100 \mathrm{hPa}$ : Panels (a) and (b) represent the average flux for period-1, period-2 during the 2002-2003 winter respectively; panels (c) and (d) represent the average flux for period-1, period-2 during the 2003-2004 winter respectively; panels (e) and (f) correspond to the average flux for period-1 and period-2 during 19992000 winter. The contours of easterly winds shown by dashed lines with intervals of $2 \mathrm{~m} / \mathrm{s}$.

zonal-mean eddy heat fluxes of period-1 and period- 2 are also analyzed to evaluate the wave activity during the three winters. The results show that, throughout the 2002-2003 and 1999-2000 winters, the westerlies were favorable conditions for the persistent upward propagation of planetary waves (see Fig. 12a, b, e and f). By contrast, the 2003-2004 winter was characterized by an anomalous wave activity during period-1 that led to a remarkable warming (see Fig. 12b). This event was followed by an abrupt decline in the wave amplitude during periods-2 (see Fig. 12d). The decline in wave amplitude during period-2 was also reflected in the disturbance of the polar mid-stratospheric temperature (see Fig. 1) and the temporal development of polar vortex shapes (see Figs. 7 to 10). This evolution of the winter dynamics was closely related to the emergence and persistence of easterly winds at high latitudes, which restricted the upward propagation of the tropospheric planetary wave, even though the waves at the $100 \mathrm{hPa}$ geopotential height were still active. 
Table 3. Total CTOF (between 1 January 15 February) (in Tg) across the extratropical tropopause poleward of $30^{\circ} \mathrm{N}$. Y represents the total meridional ozone flux across $30^{\circ} \mathrm{N}$ latitude between 95 and $286 \mathrm{hPa} ; \mathrm{Z} 1$ and $\mathrm{Z} 2$ represent the total vertical ozone flux across the $286 \mathrm{hPa}$ isobaric surface in mid-latitudes $\left(30^{\circ} \sim 60^{\circ} \mathrm{N}\right)$ and in high latitude $\left(60^{\circ} \sim 90^{\circ} \mathrm{N}\right)$ respectively. The fourth and fifth columns correspond to the total vertical ozone flux across $286 \mathrm{hPa}$ isobaric surface poleward of $30^{\circ} \mathrm{N}(\mathrm{Z} 1+\mathrm{Z} 2)$ and the total CTOF poleward of $30^{\circ} \mathrm{N}(\mathrm{Y}+\mathrm{Z} 1+\mathrm{Z} 2)$. The last two columns represent the ratio of $\mathrm{Z} 1$ to $(\mathrm{Z} 1+\mathrm{Z} 2)$ and the ratio of $\mathrm{Y}$ to $(\mathrm{Y}+\mathrm{Z} 1+\mathrm{Z} 2)$.

\begin{tabular}{cccccccc}
\hline & $\mathrm{Y}$ & $\mathrm{Z} 1$ & $\mathrm{Z} 2$ & $\mathrm{Z} 1+\mathrm{Z} 2$ & $\mathrm{Y}+\mathrm{Z} 1+\mathrm{Z} 2$ & $\mathrm{Z1} /(\mathrm{Z} 1+\mathrm{Z} 2)$ & $\mathrm{Y} /(\mathrm{Y}+\mathrm{Z} 1+\mathrm{Z} 2)$ \\
\hline $2002-2003$ & 10 & 46 & 15 & 61 & 71 & 0.75 & 0.14 \\
$2003-2004$ & 6 & 34 & 12 & 46 & 52 & 0.74 & 0.12 \\
$1999-2000$ & 5 & 57 & 1 & 58 & 63 & 0.98 & 0.08 \\
\hline
\end{tabular}

Table 1 provides quantitative values of the Brewer-Dobson circulation intensity, using the zonal mean eddy heat flux $\left(\mathrm{v}^{\prime} \mathrm{T}^{\prime}\right)$ between $45^{\circ} \sim 75^{\circ} \mathrm{N}$ on $100 \mathrm{hPa}$ surface for the three winters. The average value of the eddy heat flux during the 2003-2004 SSW event $\left(24 \mathrm{~K}^{*} \mathrm{~m} / \mathrm{s}\right)$ was slightly $\left(3 \mathrm{~K}^{*} \mathrm{~m} / \mathrm{s}\right)$ larger than that during the 2002-2003 event $\left(21 \mathrm{~K}^{*} \mathrm{~m} / \mathrm{s}\right)$ for the first month. Meanwhile, the eddy heat flux in the cold 1999-2000 winter $(10 \mathrm{~K} * \mathrm{~m} / \mathrm{s})$ was no more than half the values of the two warming winters. After the emergence of easterly winds at high latitudes, the zonal mean eddy heat flux during the 2003-2004 event was reduced by nearly 33\% (from 24 to $16 \mathrm{~K}^{*} \mathrm{~m} / \mathrm{s}$ ) during the next month. However, the eddy heat flux during the 2002-2003 event was characterized by less than $10 \%$ decrease (from 21 to $19 \mathrm{~K}^{*} \mathrm{~m} / \mathrm{s}$ ) during the same period of time, which thus surpassed the value of the heat flux at the same period during the 2003-2004 event. Moreover, the eddy heat flux in 1999-2000 case increased by $70 \%$ (from 10 to $17 \mathrm{~K}^{*} \mathrm{~m} / \mathrm{s}$ ) and is just between the values of the two warming winters. The reduced eddy heat flux and the limited propagation of planetary waves indicated there was an abrupt weakening in the so-called "extratropical pump" process (Holton et al., 1995), which produces the BrewerDobson circulation in the middle atmosphere. As a consequence, less ozone was transported poleward (see Figs. 5c, d and $6 \mathrm{c}, \mathrm{d}$ ) and downward into the extratropical UTLS region, which may have reduced the wintertime buildup of ozone in the middleworld (Wang et al., 1998).

Table 2 shows the total ozone flux (in $\mathrm{Tg}$ ) across the $100 \mathrm{hPa}$ isobaric surface over East Asia $\left(40^{\circ} \sim 65^{\circ} \mathrm{N}\right.$, $\left.70^{\circ} \sim 150^{\circ} \mathrm{E}\right)$ in the three winters. During period-1, the downward ozone flux in the early winter of 2003-2004 $(100 \mathrm{Tg})$ was only slightly smaller $(3 \mathrm{Tg})$ compared to the situation in 2002-2003 (103 Tg). Meanwhile, the value in the early 1999-2000 winter (67 Tg) was 33\% less than that in the two warming winters. These differences were related to the much stronger Brewer-Dobson circulation indicated in Table 1 for the two warming events. However, after the emergence of stratospheric easterly winds in early January 2004, with the decline of the wave activity, the downward ozone flux over East Asia changed prominently. For example, the monthly totaled downward ozone flux for 2003-2004 winter was reduced by $\sim 30 \%$ (from 100 to $71 \mathrm{Tg}$ ) during periods 2 , while the variation of ozone flux was only $\sim 19 \%$ (from 103 to $83 \mathrm{Tg}$ ) during the second month of the 2002-2003 winter. Furthermore, in the cold 1999-2000 winter, with the persistent increase of planetary wave activity, the total downward ozone flux into the lowermost stratosphere over East Asia increased by $\sim 58 \%$ in the second month (from 67 to $106 \mathrm{Tg}$ ). As on a regional scale, the magnitude of the total ozone flux is not perfectly proportional to the eddy heat flux (since the downward ozone flux is also associated with some other factors such as the horizontal advection of ozone), but there does exist a good consistency in the tendency of the ozone flux and that of the eddy heat flux during the two periods of the three winters.

In general, in terms of downward ozone flux in lower stratosphere, there are marked differences between the warming and cold winters. Moreover, the total downward ozone mass during the remarkable 2003-2004 warming winter from 15 December 2003 to 15 February $2004(171 \mathrm{Tg})$ is almost the same with that during the cold 1999-2000 winter (173 Tg) and is $\sim 10 \%$ less than that (186 Tg) in 2002-2003 warming winter (see Table 2).

\subsection{The cross-tropopause ozone flux (CTOF) in NH extra- tropics}

Anomalies in polar stratospheric circulation can propagate into the troposphere and can thus cause delayed responses in tropospheric dynamics (Baldwin and Dunkerton, 1999, 2000). In order to quantify the variations of NH extratropical CTOF associated with the stratospheric warming events, the methods from previous studies (Tie and Hess, 1997; Gettelman et al., 2004) are applied in the following context. For simplification, we total the meridional ozone flux across $30^{\circ} \mathrm{N}$ between 95 and $286 \mathrm{hPa}$ and the vertical ozone flux across $286 \mathrm{hPa}$ isobaric surface in mid-latitudes $\left(30^{\circ} \sim 60^{\circ} \mathrm{N}\right)$ and high latitudes $\left(60^{\circ} \sim 90^{\circ} \mathrm{N}\right)$ between 1 January and 15 February. 
Table 3 provides quantitative results of the total meridional and vertical CTOF in middle and high latitudes during the three winters (1 January 15 February). The extratropical total CTOF in the 2002-2003 typical SSW case (71 Tg) is $\sim 10 \%$ higher than that in the cold 1999-2000 winter (63 Tg). However, the extratropical total CTOF (52 Tg) and total vertical CTOF (46 Tg) in 2003-2004 SSW event are both 25\% lower than those (71 and $61 \mathrm{Tg}$ ) in 2002-2003 SSW event. These differences may be closely associated with the restricted wave activity in 2003-2004 event mentioned above. This may also be the reason why the extratropical total CTOF in $2003-2004(52 \mathrm{Tg})$ is $\sim 20 \%$ lower than in 1999-2000 case $(63 \mathrm{Tg})$.

More specifically, the vertical CTOFs in high latitude $\left(60^{\circ} \sim 90^{\circ} \mathrm{N}\right)$ during 2002-2003 and 2003-2004 warming winters are $15 \mathrm{Tg}$ and $12 \mathrm{Tg}$ respectively, which are 10 times more than that during the cold 1999-2000 winter $(1 \mathrm{Tg})$. However, the vertical CTOFs in mid-latitudes $\left(30^{\circ} \sim 60^{\circ} \mathrm{N}\right)$ in the two warming winters are weakened by $20 \sim 40 \%$. Moreover, compared to the case in 1999-2000 winter, the total meridional CTOF (Y) across $30^{\circ} \mathrm{N}$ between 95 and $286 \mathrm{hPa}$ in $2002-2003$ winter $(10 \mathrm{Tg})$ is doubled, while the value in 2003-2004 winter increases only by $1 \mathrm{Tg}$. Furthermore, the ratios of $\mathrm{Y}$ to the total CTOF in the two warming winters are $50 \%$, at least, higher than the cold winter. Since the meridional CTOF can approximately represent the stratosphere-troposphere exchange of ozone associated with the isentropic transport in the middleworld, above differences can be reasonably understood by the different wave activities during the three winters (see Table 1). Generally, compared to the cold winter, the increased isentropic transport associated with the enhanced wave activity during warming events plays a much more important role in the extratropical total CTOF budget.

\section{Conclusions}

This study analyzed the remarkable stratospheric sudden warming event that took place in the $\mathrm{NH}$ during the winter of 2003-2004, and compared the behavior of nitrous oxide $\left(\mathrm{N}_{2} \mathrm{O}\right)$ and ozone $\left(\mathrm{O}_{3}\right)$ during this period with the situation resulting from the major warming of 2002-2003. The present study shows that both events had significant effects on the stratospheric dynamics and on the distribution of chemical tracers. Observations by ENVISAT/MIPAS and the chemical transport model MOZART-3 were used intensively in this study. The MOZART- 3 simulations for the two winters provide distributions of ozone during the SSW events that are consistent with the ENVISAT/MIPAS observations. The observations and simulations indicate that:

(1) Both the major Arctic SSW events (2002-2003 and 2003-2004) have caused the weakening and distortion of the stratospheric polar vortex. The SSW of 2003-2004 had, however, a much more pronounced effect on the disturbance of the polar vortex, especially in the lower stratosphere. In addition, the extraordinarily long vortex disruption in the middle and lower stratosphere during the 2003-2004 event, which has caused the long-lasting wind reversal in the Arctic region has reduced the eddy heat flux and the upward propagation of planetary waves in the extratropical stratosphere. The restricted wave activity explains the rapid recovery of the upper stratospheric polar vortex and its exceptional stability during February and March 2004 (Manney et al., 2005).

(2) The distributions of $\mathrm{N}_{2} \mathrm{O}$ and $\mathrm{O}_{3}$ in the middle stratosphere bear some resemblances. They are both dynamically dominated, and affected by the isolation of the polar vortex, when the vortex is stable. The so-called "low-ozone pockets" which have been observed, are also found in the model simulations. After the occurrence of both SSW events, the polar vortex that contains low $\mathrm{N}_{2} \mathrm{O}$ and $\mathrm{O}_{3}$ concentrations is displaced from the pole. Meanwhile, poleward transport of low-latitude air with high $\mathrm{N}_{2} \mathrm{O}$ and $\mathrm{O}_{3}$ concentrations extends into the Arctic region. With the weakening of the polar vortices during the warming events, the enhanced exchanges near the vortices edge lead to a large area of low $\mathrm{N}_{2} \mathrm{O}$ and $\mathrm{O}_{3}$ concentrations outside the distorted vortices. Compared with the 2002-2003 event, the SSW of 2003-2004 results in enhanced dilution of low $\mathrm{N}_{2} \mathrm{O}$ and $\mathrm{O}_{3}$ concentrations outside the polar vortex. The presence of "low-ozone pockets" is also more prominent during the 2003-2004 SSW winter. Moreover, the transport of $\mathrm{O}_{3}$ and $\mathrm{N}_{2} \mathrm{O}$-rich air masses from the tropics is less pronounced during the 2003-2004 event due to the restricted planetary wave activity during this long-lasting warming event.

(3) Planetary wave activity, especially during the 20022003 SSW event, facilitates the downward transport of ozone in the extratropical UTLS region. However, during the 20032004 SSW event, the long-lasting easterly winds at high latitudes reduced the intrusion of ozone-rich masses from the lower stratosphere into the extratropical lowermost stratosphere (or "middleworld"), especially over East Asia. As a result, the total downward ozone transport across $100 \mathrm{hPa}$ isobaric surface by the descending branch of Brewer-Dobson circulation over East Asia was 10\% lower during the 20032004 SSW event. Moreover, compared to that in 2002-2003 warming winter (1 January 15 February), the total crosstropopause ozone flux (CTOF) during 2003-2004 winter was $\sim 25 \%$ lower, most of which could be attributed to the differences in meridional and vertical CTOF in mid-latitudes $\left(30^{\circ} \sim 60^{\circ} \mathrm{N}\right)$.

(4) Compared to the cold 1999-2000 winter, the vertical CTOF in high latitudes $\left(60^{\circ} \sim 90^{\circ} \mathrm{N}\right)$ during the $2002-$ 2003 and 2003-2004 warming events increased more than 10 times, while the vertical CTOF in mid-latitudes decreased by $20 \sim 40 \%$. Moreover, during the two warming winters, the meridional CTOF caused by the isentropic transport associating with the enhanced wave activity also increased and played an important role in the extratropical total CTOF budget. In addition, during the 2002-2003 typical SSW event, 
the extratropical total CTOF increased by $\sim 10 \%$, compared to the cold 1999-2000 winter. However, during the 20032004 SSW event, the extratropical total CTOF was even $\sim 20 \%$ lower than that during the cold winter.

Acknowledgements. The authors thank Claire Granier for his valuable comments. This work was funded by the National Science Foundation of China under Grant No. 40633015 and the ESA-NRSCC Dragon Cooperation Program (ID 5311). The National Center for Atmospheric Research is sponsored by the National Science Foundation of the USA. The authors would like to thank the ESA and MIPAS team for providing MIPAS Level 2 off-line consolidated datasets. The meteorological analysis was kindly provided by ECMWF.

Edited by: Y. Balkanski

\section{References}

Baldwin, M. P. and Holton, J. R.: Climatology of the stratospheric polar vortex and Planetary wave breaking, J. Atmos. Sci., 45, 1123-1142, 1988.

Baldwin, M. P. and Dunkerton, T. J.: Propagation of the Arctic Oscillation from the stratosphere to the troposphere, J. Geophys. Res., 104, 30937-30946, 1999.

Baldwin, M. P. and Dunkerton, T. J.: Stratospheric harbingers of anomalous weather regimes, Science, 294, 581-583, 2001.

Baldwin, M. P., Thompson, D. W. J., Shuckburgh, E. F., Norton, W. A., and Gillett, N. P.: Weather from the stratosphere?, Science, 301, 317-318, 2003.

Brasseur, G. P., Hauglustaine, D. A., Walters, S., Rasch, P. J., Muller, J. F., Granier, C., and Tie, X. X.: MOZART, a global chemical transport model for ozone and related chemical tracers 1. Model description, J. Geophys. Res., 103, 28265-28289, 1998.

Brewer, A. W.: Evidence for a world circulation provided by the measurement of helium and water vapor distribution in the stratosphere, Q. J. Roy. Meteorol. Soc., 75, 351-363, 1949.

Carli, B., Alpaslan, D., Carlotti, M., Castelli, E., Ceccherini, S., Dinelli, B. M., Dudhia, A., Flaud, J. M., Hoepfner, M., Jay, V., Magnani, L., Oelhaf, H., Payne, V., Piccolo, C., Prosperi, M., Raspollini, P., Remedios, J., Ridolfi, M., and Spang, R.: First results of MIPAS/ENVISAT with operational Level 2 code, Adv. Space Res., 33, 1012-1019, doi:10.1016/S0273-1177(03)005842, 2004.

Chen, P.: Isentropic cross-tropopause mass exchange in the extratropics, J. Geophys. Res., 100, 16661-16673, 1995.

Clilverd, M. A., Seppälä, A., Rodger, C. J., Verronen, P. T., and Thomson, N. R.: Ionospheric evidence of thermosphereto-stratosphere descent of polar $\mathrm{NO}_{\mathrm{x}}$, Geophys. Res. Lett., 33, L19811, doi:10.1029/2006GL026727, 2006.

Cortesi, U., Lambert, J. C., De Clercq, C., Bianchini, G., Blumenstock, T., Bracher, A., Castelli, E., Catoire, V., Chance, K. V., De Maziere, M., Demoulin, P., Godin-Beekmann, S., Jones, N., Jucks, K., Keim, C., Kerzenmacher, T., Kuellmann, H., Kuttippurath, J., Iarlori, M., Liu, G. Y., Liu, Y., McDermid, I. S., Meijer, Y. J., Mencaraglia, F., Mikuteit, S., Oelhaf, H., Piccolo, C., Pirre, M., Raspollini, P., Ravegnani, F., Reburn, W. J., Redaelli, G., Remedios, J. J., Sembhi, H., Smale, D., Steck, T., Taddei,
A., Varotsos, C., Vigouroux, C., Waterfall, A., Wetzel, G., and Wood, S.: Geophysical validation of MIPAS-ENVISAT operational ozone data, Atmos. Chem. Phys., 7, 4807-4867, 2007, http://www.atmos-chem-phys.net/7/4807/2007/.

Danielson, E. F.: Stratospheric-tropospheric exchange based on radioactivity, ozone and potential vorticity, J. Atmos. Sci., 25, 502518, 1968.

Dobson, G. M. B.: Origin and distribution of polyatomic molecules in the atmosphere, Proc. R. Soc. London, A236, 187-193, 1956.

Edmon, H. J., Hoskins, B. J., and McIntyre, M. E.: Eliassen-Palm cross sections for the troposphere, J. Atmos. Sci., 37, 2600-2616, 1980.

Follows, M. J., and Austin, J. F.: A zonal average model of the stratospheric contributions to the tropospheric ozone budget, J. Geophys. Res., 97, 18047-18060, 1992.

Funke, B., García-Comas, M., López-Puertas, M., Glatthor, N., Stiller, G. P., von Clarmann, T., Semeniuk, K., and McConnell, J. C.: Enhancement of $\mathrm{N}_{2} \mathrm{O}$ during the OctoberNovember 2003 solar proton events, Atmos. Chem. Phys., 8, 3805-3815, 2008, http://www.atmos-chemphys.net/8/3805/2008/.

Fusco, A. C. and Salby, M. L.: Interannual variations of total ozone and their relationship to variations of planetary wave activity, J. Climate, 12, 1619-1629, 1999.

Gettelman, A., Kinnison, D. E., Dunkerton, T. J., and Brasseur, G. P.: Impact of monsoon circulations on the upper troposphere and lower stratosphere, J. Geophys. Res., 109, D22101, doi:10.1029/2004JD004878, 2004.

Hauglustaine, D. A., Brasseur, G. P., Walters, S., Rasch, P. J., Muller, J. F., Emmons, L. K., and Carroll, C. A.: MOZART, a global chemical transport model for ozone and related chemical tracers 2. Model results and evaluation, J. Geophys. Res., 103, 28291-28335, 1998.

Haynes, P. H. and McIntyre, M. E.: On the evolution of isentropic distributions of potential vorticity in the presence of diabatic heating and frictional or other forces, J. Atmos. Sci., 48, 651678, 1987.

Haynes, P. H., Marks, C. J., McIntyre, M. E., Shepherd, T. G., and Shine, K. P.: On the "downward control" of extratropical diabatic circulations by eddy-induced mean zonal forces, J. Atmos. Sci., 48, 651-678, 1991.

Holton, J. R.: A semi-spectral numerical model for wave-mean flow interactions in the stratosphere: Application to sudden stratospheric warmings, J. Atmos. Sci., 33, 1639-1649, 1976.

Holton, J. R.: On the global exchange of mass between the stratosphere and troposphere, J. Atmos. Sci., 47, 392-395, 1990.

Holton, J. R., Haynes, P. H., McIntyre, M. E., Douglass, A. R., Rood, R. B., and Pfister, L.: Stratosphere-troposphere exchange, Rev. Geophys., 33, 403-439, 1995.

Hoppel, K., Bevilacqua, R., Allen, D., Nedoluha, G., and Randall, C.: POAM III observations of the anomalous 2002 Antarctic ozone hole, Geophys. Res. Lett., 30, 1394, doi:10.1029/2003GL016899, 2003.

Horowitz, L. W., Walters, S., Mauzerall, D. L., Emmons, L. K., Rasch, P. J., Granier, C., Tie, X. X., Lamarque, J. F., Schultz, M. G., Tyndall, G. S., Orlando, J. J., and Brasseur, G. P.: A global simulation of tropospheric ozone and related tracers: Description and evaluation of MOZART, version 2, J. Geophys. Res., 108, 4784, doi:10.1029/2002JD002853, 2003. 
Hoskins, B. J.: Towards a PV- $\theta$ view of the general circulation, Tellus, 43AB, 27-35, 1991.

Junge, C. E.: Global ozone budget and exchange between stratosphere and troposphere, Tellus, 14, 363-377, 1962.

Kinnison, D. E., Brasseur, G. P., Walters, S., Garcia, R. R., Marsh, D. R., Sassi, F., Harvey, V. L., Randall, C. E., Emmons, L., Lamarque, J. F., Hess, P., Orlando, J. J., Tie, X. X., Randel, W., Pan, L. L., Gettelman, A., Granier, C., Diehl, T., Niemeier, U., and Simmons, A. J.: Sensitivity of chemical tracers to meteorological parameters in the MOZART-3 chemical transport model, J. Geophys. Res., 112, D20302, doi:10.1029/2006JD007879, 2007.

Lait, L. R.: An alternative form for potential vorticity, J. Atmos. Sci., 51, 1754-1759, 1994.

Lelieveld, J. and Dentener, F. J.: What controls tropospheric ozone?, J. Geophys. Res., 105, 3531-3551, 2000.

López-Puertas, M., Funke, B., Gil-López, S., von Clarmann, T., Stiller, G. P., Höpfner, M., Kellmann, S., Mengistu Tsidu, G., Fischer, H., and Jackman, C. H.: $\mathrm{HNO}_{3}$, $\mathrm{N}_{2} \mathrm{O}_{5}$, and $\mathrm{ClONO}_{2}$ enhancements after the October-November 2003 solar proton events, J. Geophys. Res., 110, A09S44, doi:10.1029/2005JA011051, 2005.

Manney, G. L., Froidevaux, L., Waters, J. W., Elson, L. S., Fishbein, E. F., Zurek, R. W., Harwood, R. S., and Lahoz, W. A.: The evolution of ozone observed by UARS MLS in the 1992 late winter southern polar vortex, Geophys. Res. Lett., 20, 1279-1282, 1993.

Manney, G. L., Zurek, R. W., Oneill, A., Swinbank, R., Kumer, J. B., Mergenthaler, J. L., and Roche, A. E.: Stratospheric warmings during February and March 1993, Geophys. Res. Lett., 21, 813-816, 1994.

Manney, G. L., Froidevaux, L., Waters, J. W., Zurek, R. W., Gille, J. C., Kumer, J. B., Mergenthaler, J. L., Roche, A. E., Oneill, A., and Swinbank, R.: Formation of low-ozone pockets in the middle stratospheric anticyclone during winter, J. Geophys. Res., 100, 13939-13950, 1995.

Manney, G. L. and Sabutis, J. L.: Development of the Polar Vortex in the 1999-2000 Arctic Winter Stratosphere, Geophys. Res. Lett., 27(17), 2589-2592, 2000.

Manney, G. L., Kruger, K., Sabutis, J. L., Sena, S. A., and Pawson, S.: The remarkable 2003-2004 winter and other recent warm winters in the Arctic stratosphere since the late 1990s, J. Geophys. Res., 110, D04107, doi:10.1029/2004JD005367, 2005.

Matsuno, T.: A dynamical model of the stratospheric sudden warming, J. Atmos. Sci., 28, 1479-1494, 1971.

McIntyre, M. E. and Palmer, T. N.: Breaking planetary waves in the stratosphere, Nature, 305, 593-600, 1983.

McIntyre, M. E. and Palmer, T. N.: The "surf zone" in the stratosphere, J. Atmos. Terr. Phys., 46, 825-849, 1984.

Morris, G. A., Kawa, S. R., Douglass, A. R., Schoeberl, M. R., Froidevaux, L., and Waters, J.: Low-ozone pockets explained, J. Geophys. Res., 103, 3599-3610, 1998.

Newman, P. A. and Nash, E. R.: Quantifying the wave driving of the stratosphere, J. Geophys. Res., 105, 12485-12497, 2000.

Pan, L. L., Wei, J. C., Kinnison, D. E., Garcia, R. R., Wuebbles, D. J., and Brasseur, G. P.: A set of diagnostics for evaluating chemistry-climate models in the extratropical tropopause region, J. Geophys. Res., 112, D09316, doi: 10.1029/2006JD007792, 2007.

Pancheva, D., Mukhtarov, P., Mitchell, N. J., Merzlyakov, E.,
Smith, A. K., Andonov, B., Singer, W., Hocking, W., Meek, C., Manson, A., and Murayama, Y.: Planetary waves in coupling the stratosphere and mesosphere during the major stratospheric warming in 2003/2004, J. Geophys. Res., 113, D12105, doi:10.1029/2007JD009011, 2008.

Park, M., Randel, W. J., Kinnison, D. E., Garcia, R. R., and Choi, W.: Seasonal variation of methane, water vapor, and nitrogen oxides near the tropopause: Satellite observations and model simulations, J. Geophys. Res., 109, D03302, doi:10.1029/2003JD003706, 2004.

Plumb, R. A.: Stratospheric transport, J. Meteor. Soc. Japan, 80, 793-809, 2002.

Ramanathan, V., Callis, L. B., and Boughner, R. E.: Sensitivity of surface temperature and atmospheric temperature to perturbations in the stratospheric concentration of ozone and nitrogen dioxide, J. Atmos. Sci., 33, 1092-1112, 1976.

Ramanathan, V.: Troposphere-stratosphere feedback mechanism: stratospheric warming and its effect on the polar energy budget and the tropospheric circulation, J. Atmos. Sci., 34, 439-447, 1977.

Ramanathan, V. and Dickinson, R. E.: The role of stratospheric ozone in the zonal and seasonal radiative energy balance of the earth-troposphere system, J. Atmos. Sci., 36, 1084-1104, 1979.

Randall, C. E., Harvey, V. L., Manney, G. L., Orsolini, Y., Codrescu, M., Sioris, C., Brohede, S., Haley, C. S., Gordley, L. L., Zawodny, J. M., and Russell, J. M.: Stratospheric effects of energetic particle precipitation in 2003-2004, Geophys. Res. Lett., 32, L05802, doi:10.1029/2004GL022003, 2005.

Raspollini, P., Belotti, C., Burgess, A., Carli, B., Carlotti, M., Ceccherini, S., Dinelli, B. M., Dudhia, A., Flaud, J. M., Funke, B., Hopfner, M., Lopez-Puertas, M., Payne, V., Piccolo, C., Remedios, J. J., Ridolfi, M., and Spang, R.: MIPAS level 2 operational analysis, Atmos. Chem. Phys., 6, 5605-5630, 2006, http://www.atmos-chem-phys.net/6/5605/2006/.

Ridolfi, M., Blum, U., Carli, B., Catoire, V., Ceccherini, S., Claude, H., De Clercq, C., Fricke, K. H., Friedl-Vallon, F., Iarlori, M., Keckhut, P., Kerridge, B., Lambert, J. C., Meijer, Y. J., Mona, L., Oelhaf, H., Pappalardo, G., Pirre, M., Rizi, V., Robert, C., Swart, D., von Clarmann, T., Waterfall, A., and Wetzel, G.: Geophysical validation of temperature retrieved by the ESA processor from MIPAS/ENVISAT atmospheric limb-emission measurements, Atmos. Chem. Phys., 7, 4459-4487, 2007, http://www.atmos-chem-phys.net/7/4459/2007/.

Roelofs, G.-J. and Lelieveld, J.: Model study of the influence of cross-tropopause $\mathrm{O}_{3}$ transports on tropospheric $\mathrm{O}_{3}$ levels, Tellus, 49B, 38-55, 1997.

Rohen, G., von Savigny, C., Sinnhuber, M., Llewllyn, E. J., Kaiser, J. W., Jackman, C. H., Kallenrode, M.-B., Schröter, J., Eichmann, K.-U., Bovensmann, H., and Burrows, J. P.: Ozone depletion during the solar proton events of October/November 2003 as seen by SCIAMACHY, J. Geophys. Res., 110, A09S39, doi:10.1029/2004JA010984, 2005.

Rosenlof, K. H. and Holton, J. R.: Estimates of the stratospheric residual circulation using the downward control principle, J. Geophys. Res., 98, 10465-10479, 1993.

Salby, M. L. and Callaghan, P. F.: Influence of planetary wave activity on the stratospheric final warming and spring ozone, J. Geophys. Res., 112, D20111, doi:10.1029/2006JD007536, 2007.

Scherhag, R.: Die explosionsartigen stratospharener warmungen 
des spatwinters 1951-1952, Berit. Dtsch. Wetterdienst, 6, 1952.

Seppälä, A., Clilverd, M. A., and Rodger, C. J.: $\mathrm{NO}_{\mathrm{x}}$ enhancements in the middle atmosphere during 2003-2004 polar winter: Relative significance of solar proton events and the aurora as a source, J. Geophys. Res., 112, D23303, doi:10.1029/2006JD008326, 2007.

Thompson, D. W. J. and Wallace, J. M.: The Arctic Oscillation signature in the wintertime geopotential height and temperature fields, Geophys. Res. Lett., 25, 1297-1300, 1998.

Tie, X. X. and Brasseur, G.: The response of stratospheric ozone to volcanic eruptions: Sensitivity to atmospheric chlorine loading, Geophys. Res. Lett., 22, 3035-3038, 1995.

Tie, X. X. and Hess, P.: Ozone mass exchange between the stratosphere and troposphere for background and volcanic sulfate aerosol conditions, J. Geophys. Res., 102, 25487-25500, 1997.

Varotsos, C.: The Southern Hemisphere Ozone Hole Split in 2002, ESPR Environ. Sci. \& Pollut. Res., 9(6), 375-376, 2002.
Vigouroux, C., De Mazière, M., Errera, Q., Chabrillat, S., Mahieu, E., Duchatelet, P., Wood, S., Smale, D., Mikuteit, S., Blumenstock, T., Hase, F., and Jones. N.: Comparisons between groundbased FTIR and MIPAS $\mathrm{N}_{2} \mathrm{O}$ and $\mathrm{HNO}_{3}$ profiles before and after assimilation in BASCOE, Atmos. Chem. Phys., 7, 377-396, 2007, http://www.atmos-chem-phys.net/7/377/2007/.

Vogel, B., Konopka, P., Grooß, J.-U., Müller, R., Funke, B., LópezPuertas, M., Reddmann, T., Stiller, G., von Clarmann, T., and Riese, M.: Model simulations of stratospheric ozone loss caused by enhanced mesospheric $\mathrm{NO}_{\mathrm{x}}$ during Arctic Winter 2003/2004, Atmos. Chem. Phys., 8, 5279-5293, 2008, http://www.atmos-chem-phys.net/8/5279/2008/.

Wang, P. H., Cunnold, D. M., Zawodny, J. M., Pierce, R. B., Olson, J. R., Kent, G. S., and Skeens, K. M.: Seasonal ozone variations in the isentropic layer between 330 and $380 \mathrm{~K}$ as observed by SAGE II: Implications of extratropical cross-tropopause transport, J. Geophys. Res., 103, 28647-28659, 1998. 